\title{
Incidence of virus fungal diseases on three stone fruits cultivars in Hungary
}

\author{
Holb, I.J. ${ }^{1}$, Soltész, M. ${ }^{1,3}$, Nyéki J. ${ }^{1}$ \& Szabó, Z. ${ }^{1}$ \\ ${ }^{1}$ Debrecen University, Centre of Agricultural Sciences and Applied Economics, \\ H-4015 Debrecen, Böszörményi Street 138, Hungary; holb@agr.unideb.hu \\ ${ }^{2}$ College of Kecskemét, Faculty of Horticulture, Department of Fruit Growing, \\ H-6000 Kecskemét, Erdei Ferenc tér 1-3 \\ ${ }^{3}$ Fruit Research Institute, $H-6000$ Kecskemét
}

\begin{abstract}
Summary: In this two-year study, incidence of Polystigma rubrum on plum, and Apiognomonia erytrostoma on apricot were evaluated on several stone fruit cultivars in Hungary. Results showed that most apricot cultivars expressed symptoms caused by A. erytrostoma, graded between 2 and $3(10-50 \%)$ by the end of the summer in 2005 and 2006. The most tolerant apricot cultivars were Budapest and Mandulakajszi while the most susceptible ones were 'Magyar kajszi' and 'Piroska'. Assessments made on plum showed that most of the plum cultivars were tolerant or lowly susceptible to P. rubrum such as 'Ageni', 'Althann ringló', 'Bluefre', 'Cacanska najbolja', 'Silvia', 'Ruth Gerstetter', 'Tuleu gras' and 'Utility'. The most susceptible plum cultivars to P. rubrum were 'Besztercei clones' and 'Debreceni Muskotály'.
\end{abstract}

Key words: Polystigma rubrum, plum, Apiognomonia erytrostoma, apricot

\section{Introduction}

Among stone fruit diseases, those fungal pathogens are of great importance which cause early leaf fall and fruit rot. Due to early leaf fall, nutrient accumulation stops from leaves to buds. Consequently, bud formation in summer is delayed and buds cannot develop fully by autumn as well as their susceptibility to frost injury increases during winter and next spring. Fungal pathogens causing early leaf fall include Polystigma rubrum on plum and Apiognomonia erytrostoma on apricot (Holb \& Erdös, 2005; Holb, 2005; Holb et al., 2007). Among fruit rot pathogens Monilinia spp. (mainly $M$. fructigena and $M$. laxa) the most important stone fruit disease. Since the pathogens are wound parasites, it appears on the fruits at injuries after hail or strong pest damage. Brown rotting of fruits starts and then grey conidiophores appears on their surface. The fruits often mummify and stay on the tree. The primary inoculum sources of the disease are the dead woody parts and the fruit mummies. The disease can also cause significant damages during storage. Its host plants include the stone fruit species (Holb, 2004, 2006).

Some studies evaluated susceptibility of stone fruit cultvars to fungal diseases which cause early leaf fall. On plum, study of Szabó (1997b) and Soltész (1998) showed that 'Ageni', 'Althann ringló', 'Silvia', 'Ruth Gerstetter', and 'Utility' expressed no or little symptoms caused by $P$. rubrum. In this study, 'Debreceni Muskotály' and 'Korai besztercei' cultivars were highly susceptible to $P$. rubrum. In a Bulgarian study, 'Ahatan', 'Sofia-2', 'Gilej', 'Strinava' and 'Stanley' cultivars were partially resistant, while 'Green gage' and 'Cacanska najbolja' cultivars were highly susceptible to P. rubrum (Borovinova, 2002). On apricot, Békési et al. (2000) demonstrated that cultivars 'Mammia', 'Tomis' and 'Nugget' showed less severe symptoms of $A$. erytrostoma in the rainy years of 1999 than all other apricot cultivars. Study of Szabó (1997a) revealed that cultivars 'Magyar kajszi' and 'Piroska' were less susceptible to $A$. erytrostoma compared to commonly grown cultivars in Hungary.

Szabó (1997a) classified several apricot cultivars into brown rot susceptibility groups. He evaluated cvs. 'Budapest' and 'Mandulakajszi' as highly, 'Ceglédi óriás', 'Liget óriás' and 'Polonais' as moderately and 'Borsi-féle kései rózsa', 'Piroska', 'Pannónia', 'Ceglédi bíborkajszi', 'Magyar kajszi' and 'Rakovszky' as lowly susceptible to blossom and twig blights caused by M. laxa. In the case of plum, fruit rot is the most important damage but flower infection can also occur. Such features as vulnerable fruit peeling, long, wet weather periods during fruit maturity and clustering of fruits, are the main factors responsible for susceptibility to brown rot infection (Soltész, 1997). Szabó (1997b) classified several European plum cultivars into brown rot susceptibility groups. He found that 'Bluefre', 'President' and 'Stanley' are highly, 'Cacanska najbolja' and 'President' are moderately, and 'Besztercei', 'Silvia' and 'Tuleu gras' are lowly susceptible to fruit rot caused by M. laxa.

These pathogens are causing severe infections in Hungarian stone fruit orchards if the summer is rainy. The amount of precipitation was higher in summers of 2008 and 2009 which allowed detailed investigation on early leaf fall 
pathogens on sour cherry cultivars. Similar study was performed int he summers of 2005 and 2006.

\section{Materials and methods}

\section{Orchard site and disease assessments}

The study was performed at Kecskemét in the experimetal orchards of the Fruit Research Station. At Kecskemét, 13 apricot and 17 plum cultivars were evaluated for infections caused by $A$. erytrostoma and $P$. rubrum, respectively. Assessments were made in late summers of 2005 and 2006. All assessments were made on all the available trees or at least four trees per cultivar. In each tree, 200 leaves were evaluated for symptoms. Assessed leaves were classified into six groups according to their infection degree. Categories were defined on the basis of the area of the infected surface. On the 0-5 scale, the bigger numbers mean stronger infection. Leaves in grade 0 were without symptoms. Leaves in grade 1 were healthy on most part of the leaf-surface, the infected area did not exceed $10 \%$ of the total surface. Leaves in grade 2 were still healthy on most part of the leaf-surface, the infected area was between 10 and $25 \%$ of the total surface.In grade $3,25-50 \%$ of the leafesurface was covered with leaf spots. Leaves of grade 4 had an infected area between 50-75\%. In grade 5, the infected area was over $75 \%$. Similar grade (1-5) was used for evaluating fruit rot on 50 fruit/tree on four trees / cultivar. Data for each disease and cultivar were averaged and then analysed by using one-way analyses of variance using Excel PC programme.

\section{Results and discussion}

\section{A. erytrostoma}

Assessment made in apricot in 2008 showed that most cultivars expressed symptoms caused by A. erytrostoma grading between 2 and $3(10-50 \%)$ by the end of the summer

Table 1. Susceptibility of apricot cultivars to Apiognomonia erytrostoma (Kecskemét, 2008-2009)

\begin{tabular}{|l|c|c|}
\hline & \multicolumn{2}{|c|}{ Disease grade (0-5) } \\
\hline Cultivars & $\mathbf{2 0 0 8}$ & $\mathbf{2 0 0 9}$ \\
\hline Bergeron & 3 & 3 \\
\hline Borsi-féle korai rózsa & 2 & 3 \\
\hline Budapest & 1 & 1 \\
\hline Ceglédi bíbor & 2 & 3 \\
\hline Ceglédi óriás & 3 & 3 \\
\hline Korai piros & 3 & 2 \\
\hline Magyar kajszi & 5 & 4 \\
\hline Mandulakajszi & 1 & 1 \\
\hline Pannónia & 4 & 2 \\
\hline Piroska & 3 & 3 \\
\hline Rakovszky & 4 & 3 \\
\hline Rózsakajszi & 3 & 2 \\
\hline
\end{tabular}

in 2005. The most tolerant cultivars were 'Budapest' and 'Mandulakajszi' while the most susceptible ones were 'Magyar kajszi', 'Pannónia' and 'Rakovszky' (Table 1). In 2009, apricot cultivars showed similar susceptibility to $A$. erytrostoma as in 2008. Again, the most tolerant cultivars were 'Budapest' and 'Mandulakajszi' while the most susceptible one was 'Magyar kajszi' (Table 1).

\section{P. rubrum}

Assessments made on plum in 2008 and 2009 showed that most of the plum cultivars were tolerant or lowly susceptible to P. rubrum such as 'Ageni', 'Althann ringló', 'Bluefre', 'Cacanska najbolja', 'Silvia', 'Tuleu gras' and 'Utility'. The most susceptible cultivars were 'Besztercei clones' and 'Debreceni Muskotály' (Table 2).

Table 2. Susceptibility of plum cultivars to Polystigma rubrum (Kecskemét, 2008-2009)

\begin{tabular}{|l|c|c|}
\hline & \multicolumn{2}{|c|}{ Disease grade (0-5) } \\
\hline Cultivars & $\mathbf{2 0 0 8}$ & $\mathbf{2 0 0 9}$ \\
\hline Ageni & 1 & 0 \\
\hline Althann ringló & 0 & 0 \\
\hline Besztercei szilva & 4 & 5 \\
\hline Bluefre & 0 & 0 \\
\hline Cacanska lepotica & 2 & 3 \\
\hline C. najbolja & 0 & 0 \\
\hline C. rodna & 3 & 4 \\
\hline Centenar & 2 & 2 \\
\hline Debreceni muskotály & 4 & 4 \\
\hline Korai besztercei & 5 & 5 \\
\hline Olaszkék & 3 & 2 \\
\hline President & 2 & 3 \\
\hline Silvia & 0 & 0 \\
\hline Stanley & 3 & 2 \\
\hline Tuleu gras & 0 & 1 \\
\hline Utility & 0 & 0 \\
\hline
\end{tabular}

Table 3 Susceptibility of fruit of apricot cultivars to Monilinia spp. (Kecskemét, 2008-2009)

\begin{tabular}{|l|c|c|}
\hline & \multicolumn{2}{|c|}{ Disease grade (0-5) } \\
\hline Cultivars & $\mathbf{2 0 0 8}$ & $\mathbf{2 0 0 9}$ \\
\hline Bergeron & 4 & 4 \\
\hline Borsi-féle korai rózsa & 1 & 1 \\
\hline Budapest & 4 & 4 \\
\hline Ceglédi bíbor & 2 & 3 \\
\hline Ceglédi óriás & 4 & 4 \\
\hline Korai piros & 3 & 3 \\
\hline Magyar kajszi & 3 & 2 \\
\hline Mandulakajszi & 5 & 5 \\
\hline Pannónia & 1 & 2 \\
\hline Piroska & 1 & 2 \\
\hline Rakovszky & 1 & 2 \\
\hline Rózsakajszi & 2 & 3 \\
\hline
\end{tabular}




\section{Monilinia spp.}

Assessment made in apricot showed that most cultivars expressed symptoms caused by Monilinia spp. grading between 2 and $4(10-75 \%)$ by the end of the summer in 2008. The most tolerant cultivars were 'Borsi-féle kései rózsa', 'Piroska', 'Pannónia', 'Magyar kajszi' and 'Rakovszky' while the most susceptible ones were cvs. 'Budapest' and 'Mandulakajszi' (Table 3). Assessments on plum showed that only cultivars 'Besztercei', 'Silvia' and 'Tuleu gras' were tolerant to Monilinia spp., while the most susceptible cultivars were 'Bluefre' and 'Stanley' (Table 4).

Table 4 Susceptibility of fruit of plum cultivars to Monilinia spp. (Kecskemét, 2008-2009)

\begin{tabular}{|l|c|c|}
\hline & \multicolumn{2}{|c|}{ Disease grade (0-5) } \\
\hline Cultivars & $\mathbf{2 0 0 8}$ & $\mathbf{2 0 0 9}$ \\
\hline Ageni & 3 & 3 \\
\hline Althann ringló & 2 & 1 \\
\hline Besztercei szilva & 2 & 5 \\
\hline Bluefre & 4 & 2 \\
\hline Cacanska lepotica & 3 & 3 \\
\hline C. najbolja & 3 & 3 \\
\hline C. rodna & 3 & 3 \\
\hline Centenar & 3 & 3 \\
\hline Debreceni muskotály & 3 & 2 \\
\hline Korai besztercei & 1 & 3 \\
\hline Olaszkék & 3 & 3 \\
\hline President & 3 & 1 \\
\hline Silvia & 1 & 4 \\
\hline Stanley & 4 & 2 \\
\hline Tuleu gras & 2 & 3 \\
\hline Utility & 1 & \\
\hline
\end{tabular}

\section{Acknowledgements}

Support of the Ministry of Agriculture and Rural Development (project number: NKFP) highly acknowledged. The study was partly supported by the Hungarian Scientific Research Fund (OTKA K78399) and a János Bolyai Research Fellowship awarded to I. Holb.

\section{References}

Békési, P. Gergely, L., Jakab, L-né., Auguszta, Gy-né., Bartus, E., Birtáné Vas, Zs. Hertelendy, P., Orlócziné Debreceni, A. \& Viola, J-né. (2000): Országos Mezőgazdasági Intézet Növénykórtani Osztály 1999. évi munkája. I. kötet. OMMI, Budapest, 156 pp.

Borovinova, M. (2002): Susceptibility of plum cultivars to red leaf spot Polystigma rubrum (Persoon) De Candolle. ISHS Acta Horticulturae 577: VII. International Symposium on Plum and Prune Genetics, Breeding and Pomology

Holb, I. J. (2004): The brown rot fungi of fruit crops (Monilinia spp.) III. Important features of their disease control (Review). International Journal of Horticultural Science, 10 (4): 31-48.

Holb, I. (2005): A szilva jelentősebb kórokozói. pp. 193-195. In: Holb, I. (szerk.) A gyümölcsösök és a szőlő ökológiai növényvédelme. Mezőgazda Kiadó, Budapest

Holb, I. J. (2006): Possibilities of brown rot management in organic stone fruit production in Hungary. International Journal of Horticultural Science, 12 (3): 87-92.

Holb, I. \& Erdős, F. (2005): A kajszi jelentősebb kórokozói. pp. 172-175. In: Holb, I. (szerk.) A gyümölcsösök és a szőlő ökológiai növényvédelme. Mezőgazda Kiadó, Budapest

Holb, I.J., Drén, G., Thurzó, S., Erdős, Z., Soltész, M. \& Szabó, Z. (2007): Incidence of virus and fungal diseases on apricot, cherry and plum cultivars in Hungary. Int J. Hort. Sci., 13 (1): 29-32.

Soltész, M. (1997): Kórokozókkal és kártevőkkel szembeni ellenállóság. 71-84. In: Soltész M. (ed.) Integrált gyümölcstermesztés. Mezőgazda Kiadó, Budapest

Szabó, Z. (1997a): Kajszi. 587-599. In: Soltész, M. (ed.): Integrált gyümölcstermesztés. Mezőgazda Kiadó, Budapest

Szabó, Z. (1997b): Szilva. 600-619. In: Soltész, M. (ed.): Integrált gyümölcstermesztés. Mezőgazda Kiadó, Budapest

Soltész, M. (1998): A fajták megválasztása. p. 119-154. In: Soltész M. (eds.): Gyümölcsfajtaismeret és -használat. Mezőgazda, Budapest. 